\title{
Nitrate removal from water using alum and ferric chloride: A comparative study of alum and ferric chloride efficiency
}

\author{
Ali Ahmad Aghapour ${ }^{1}$, Sepideh Nemati², Amir Mohammadi ${ }^{*}$, Heshmatollah Nourmoradi $^{3}$, Sima Karimzadeh $^{2}$ \\ ${ }^{1}$ Assistant Professor of Environmental Health Engineering, Department of Environmental Health Engineering, School of Health, Urmia \\ University of Medical Sciences, Urmia, Iran \\ ${ }^{2} \mathrm{MSc}$ of Environmental Health Engineering, Student Research Committee, School of Health, Urmia University of Medical Sciences, \\ Urmia, Iran \\ ${ }^{3}$ Assistant Professor of Environmental Health Engineering, Department of Environmental Health Engineering, School of Health, Ilam \\ University of Medical Sciences, Ilam, Iran
}

\begin{abstract}
Background: Nitrate is an acute and well-known hazardous contaminant, and its contamination of water sources has been a growing concern worldwide in recent years. This study evaluated the feasibility of nitrate removal from water using the traditional coagulants alum and ferric chloride with lower concentrations than those used in the conventional coagulation process.

Methods: In this research, two coagulants, alum and ferric chloride, were compared for their efficiency in removing nitrate in a conventional water treatment system. The removal process was done in a batch system (jar test) to examine the effects of coagulant dosages and determine the conditions required to achieve optimum results.

Results: The results revealed that ferric chloride at an initial dose rate of $4 \mathrm{mg} / \mathrm{L}$ reduced nitrate concentration from $70 \mathrm{mg} / \mathrm{L}$ to less than the World Health Organization (WHO) guideline value $(50 \mathrm{mg} / \mathrm{L}$ $\mathrm{N}-\mathrm{NO}_{3}$ ). However, the removal efficiency of alum was not salient to significant nitrate reduction. Conclusion: In conclusion, ferric chloride was more effective than alumin removing $\mathrm{NO}_{3}^{-}$, even in common dosage range, and can be considered a cost-effective and worthy treatment option to remediate nitratepolluted water. Furthermore, the removal of nitrate by coagulation can be simple and more economical than other treatment alternatives.

Keywords: Nitrate, Water treatment, Coagulation, Alum, Ferric chloride

Citation: Aghapour AA, Nemati S, Mohammadi A, Nourmoradi H, Karimzadeh S. Nitrate removal from water using alum and ferric chloride: a comparative study of alum and ferric chloride efficiency. Environmental Health Engineering and Management Journal 2016; 3(2): 69-73. doi: 10.15171/ EHEM.2016.03.
\end{abstract}

\section{Article History:}

Received: 5 February 2016

Accepted: 3 March 2016

ePublished: 26 March 2016

\section{Introduction}

Nitrate $\left(\mathrm{NO}_{3}^{-}\right)$is found naturally in the environment and is an important plant nutrient (1). However, the contamination of water sources by nitrate has been a growing concern worldwide in recent years (2). Nitrate in water sources is related to nitrogen fertilizer and domestic wastewater (3). This problem is found in both developed and developing countries. In European Union (EU) countries, nitrate concentrations in $20 \%$ of groundwater resources

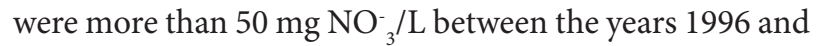
$1998(4,5)$. In several Middle Eastern countries, including some places in Iran (6), Iraq (7), Saudi Arabia (8), and the United Arabic Emirates (9), high nitrate concentrations have been detected in ground water. Nitrate causes disease and negatively affects health with such issues as methemoglobinemia, goiter, thyroid disorder, stomach cancer, cytogenetic defects, and birth defects $(10,11)$. The maximum concentration level (MCL) of nitrate is $50 \mathrm{mg} \mathrm{NO}_{3} / \mathrm{l}$ as set by the World Health Organization (WHO) standards for drinking water, and the Environmental Protection Agency (EPA) and EU have determined the MCL of nitrate to be 10 and $11.3 \mathrm{mg} \mathrm{N} / \mathrm{L}$, respectively (12-14). Thus, the removal of nitrate from contaminated water for drinking purposes is important.

There are numerous physical and chemical methods to remove nitrate from water, including ion exchange, reverse osmosis, and electrodialysis. These methods are useful but produce concentrated brine as a waste by-product which should be treated or disposed of, and this requires expensive processes $(6,12)$.

Nitrogen and phosphorus compounds are typically removed from wastewater with biological processes. Biological denitrification is an extensively used procedure for the reduction of nitrate from water and wastewater (15). 
The most significant problem with the denitrification process is that it requires disinfection in order to remove bacteria. Furthermore, this process is very sensitive to some parameters, such as temperature, $\mathrm{pH}$, conductivity, and toxic compounds $(10,12,16)$. Other biological treatment options include treatment using fluidized beds or a fixed bed and membrane biofilm reactor. Chemical reduction methods using media such as zero valent iron (ZVI) and sulfur modified iron (SMI) have also been used recently $(17,18)$.

Coagulation and flocculation may be broadly described as chemical and physical processes that mix coagulating chemicals and flocculation aids with water. Coagulation destabilizes particles and enables them to become attached to other particles so that they may be removed in subsequent processes (19). Three main mechanisms, electrostatic coagulation (reduction of electrostatic forces and separation of particles), sweep coagulation (entrapment of particles by coagulant metal-hydroxides), and adsorptive coagulation (destabilization by adsorption of polymers or long hydroxide chains to the particle surface), are considered for the coagulation/flocculation process (20).

In summary, these processes are low-cost, simple methods for the destabilization of suspended particles and the removal of turbidity, natural organic matter (NOM), disinfection by product precursors or color in raw water.

$\mathrm{Al}(\mathrm{III})$ and $\mathrm{Fe}(\mathrm{III})$ coagulants are two main inorganic compounds used in water treatment plants. Ferric sulphate, aluminum sulphate, and ferric chloride are the most common coagulants $(21,22)$.

The main source of drinking water in most of Iran's cities is ground water, which generally contains higher concentrations of nitrate. The current study aimed to evaluate the feasibility of nitrate removal from drinking waters with conventional coagulation treatments by applying alum and ferric chloride in a batch system. Furthermore, the efficiency rates of nitrate removal by alum and ferric chloride were compared, and the effects of factors such as initial nitrate concentration and coagulant dosage were studied.

\section{Methods}

Containers and synthetic water preparation

All containers were glass. They were washed with diluted acid $\left(\mathrm{H}_{2} \mathrm{SO}_{4}, 10 \%\right)$ and then rinsed with tap water and deionized water. Synthetic water samples in concentrations of $10,30,50,70$, and $100 \mathrm{mg} / \mathrm{L} \mathrm{NO}_{3}^{-} \mathrm{N}$ were prepared from nitrate stock solution (dissolving $\mathrm{KNO}_{3}$ [Merck Co., 99.0\%] in tap water). All samples were stored at temperatures below $4^{\circ} \mathrm{C}$, and experiments were carried out within 24 hours of sample preparation. The main source of tap water was groundwater with no special treatment except chlorination. The physico-chemical characteristics of the tap water are shown in Table 1.

\section{Experimental procedure}

In this study, the most common coagulants, i.e. alum (aluminum sulfate, $\left.\mathrm{Al}_{2}\left(\mathrm{SO}_{4}\right)_{3}\right)$ and ferric chloride $\left(\mathrm{FeCl}_{3}\right)$,
Table 1. Physico-chemical characteristics of tap water

\begin{tabular}{lc}
\hline Parameter & Values \\
\hline $\mathrm{pH}$ & $7 \pm 0.2$ \\
$\mathrm{EC}(\mu \mathrm{S} / \mathrm{cm})$ & 690 \\
Temperature $\left({ }^{\circ} \mathrm{C}\right)$ & $20 \pm 2$ \\
Turbidity $(\mathrm{NTU})$ & 0.5 \\
Alkalinity $(\mathrm{mg} / \mathrm{L})$ & 317 \\
$\mathrm{TDS}^{-\mathrm{mg} / \mathrm{L})}$ & 448 \\
$\mathrm{SO}_{4}^{-}(\mathrm{mg} / \mathrm{L})$ & 58 \\
$\mathrm{Cl}(\mathrm{mg} / \mathrm{L})$ & 21 \\
$\mathrm{Total} \mathrm{Hardness}(\mathrm{mg} / \mathrm{L})$ & 285 \\
$\mathrm{Mg}(\mathrm{mg} / \mathrm{L})$ & 25 \\
$\mathrm{Ca}(\mathrm{mg} / \mathrm{L})$ & 72 \\
$\mathrm{Na}(\mathrm{mg} / \mathrm{L})$ & 33 \\
$\mathrm{~K}(\mathrm{mg} / \mathrm{L})$ & 4 \\
\hline
\end{tabular}

were applied to determine the nitrate removal efficiency of a conventional water treatment system.

The coagulation-flocculation process was performed in a batch system (jar test) with a six-paddle stirrer (Hach), and the chemicals, dosages, and conditions required to achieve optimum results were evaluated (ASTM, 1995). The alum and ferric chloride solutions at desired concentrations were prepared by diluting the stock solution [10 $\mathrm{g} / \mathrm{L}]$ immediately before use. Coagulant dosages for the removal of nitrate were $2.5,3,3.5,4$, and $4.5 \mathrm{mg} / \mathrm{L}$.

Conventional coagulation by alum depends on $\mathrm{pH}$ and temperature (23); in this study, the $\mathrm{pH}$ values of solutions were around $7 \pm 0.2$, and tests were conducted at room temperature which is recommended for $\mathrm{FeCl}_{3}$ and alum usage. Acidic $\mathrm{pH}$ may lead to the formation of weak $\mathrm{HNO}_{3}$ ions or the complexation of $\mathrm{NO}_{3}{ }^{-}$ions with dissolved aluminum (24). Therefore, in this study, acidic $\mathrm{pH}$ was not applied. Furthermore, as reported in the literature, a $\mathrm{pH}$ above 9 is not efficient in the coagulation process for nitrate removal (25).

Rapid mixing was simulated for 1 minute at $120 \mathrm{rpm}$ and flocculation was done by slow mixing at $20 \mathrm{rpm}$ for 15 minutes. The flocs were then allowed to settle for $20 \mathrm{~min}$ utes without mixing.

\section{Sample analyses}

The samples were analyzed for residual nitrate concentration using a UV spectrophotometer apparatus $(\mathrm{HACH}$ $\mathrm{DR} / 5000$ ) at a wavelength of $220 \mathrm{~nm}$ according to the 1998 standard methods for the examination of water and wastewater (4500- $\mathrm{NO}_{3}{ }^{-}$B) (5).

The $\mathrm{pH}$ values of samples were measured with a $\mathrm{pH}$ meter WTW 3110 at the end of the settling period.

Statistical analysis

The data acquired from the comparative surveys was analyzed by SPSS 16.0 for Windows (Chicago, IL, USA). Due to the lack of normal data distribution, the non-parametric statistics analysis Mann-Whitney $U$ Test was used to further analyze the data. All data was analyzed with Microsoft Excel 2007. 
Results

The effect of initial nitrate concentration on the efficiency of the conventional coagulation-flocculation process was investigated at different nitrate concentrations $(10,30$, 50, 70, and $100 \mathrm{mg} / \mathrm{L} \mathrm{N}-\mathrm{NO}_{3}$ ). The removal percentages of different concentrations of nitrate using ferric chloride and alum as a function of coagulant dosages are separately presented in Figure 1. Results of the Mann-Whitney U tests showed significant differences in the abilities of ferric chloride and alum to remove nitrate $(P<0.01)$.

Clearly, ferric chloride exhibited a greater removal efficiency than aluminum sulfate. As can be seen, the nitrate uptake by both ferric chloride and alum decreased when the initial nitrate concentrations were increased from 10 to $100 \mathrm{mg} / \mathrm{L} \mathrm{N}-\mathrm{NO}_{3}$.

Figure 2 shows the typical operating ranges for the coagulants. Taking into account the primary $\mathrm{pH}$ values and optimum dosages of coagulants, the predominant removal mechanisms for nitrate could be attributed to adsorption and sweep precipitation.

\section{Discussion}

Effect of initial nitrate concentration and coagulant dose As seen in Figure 1, ferric chloride removed nitrate with a higher efficiency than that of alum. Results of the MannWhitney $U$ test also showed significant differences in ferric chloride and alum abilities for nitrate removal $(P<0.01)$.

The highest removal efficiency rate using each one of the applied coagulants was obtained for an initial nitrate concentration of $10 \mathrm{mg} / \mathrm{LN}-\mathrm{NO}_{3}$, and minimum removal was found for a $100 \mathrm{mg} / \mathrm{LN}-\mathrm{NO}_{3}$ concentration (see Figure 1). When initial nitrate concentration was 10 and $30 \mathrm{mg} / \mathrm{LN}-$ $\mathrm{NO}_{3}$, the removal fraction using $\mathrm{Fecl}_{3}$ was more than $90 \%$; however, for $70 \mathrm{mg} / \mathrm{LN}-\mathrm{NO}_{3}$, it was reduced to less than $35 \%$ even when applying the highest coagulant dose (4 $\mathrm{mg} / \mathrm{L})$. Thus, it can be concluded that when the concentration of the contaminant is increased, removal efficiency is decreased. This is true for alum as well.

Koparal and Ögütveren achieved similar results in the removal of nitrate from water by an electrochemical process and reported that removal efficiency was inversely related to initial nitrate concentration (26). It seems that increasing nitrate concentration is an important factor effecting the removal of nitrate from water.

The experimental results also showed removal restrictions in concentrations above $50 \mathrm{mg} / \mathrm{L}$ of pollutant, and ferric chloride was more effective in the removal of low ranges of $\mathrm{N}^{-\mathrm{NO}_{3}^{-}}(<30 \mathrm{mg} / \mathrm{L})$. Similarly, another study which investigated nitrate removal from water by a coagulation process reported removal efficiency as $85 \%$ when $0.3 \mathrm{~g}$ of hydrotalcite-like compounds were used in the $\mathrm{NO}_{3}^{-}$ solution with an initial concentration of $10 \mathrm{mg} / \mathrm{L} \mathrm{(27).}$ Nonetheless, the optimum dosage of ferric chloride in the current study was $4 \mathrm{mg} / \mathrm{L}$, which is less than the typically used coagulation dosage in the water treatment industry. In the case of alum, applied dosages ranged from 2.5 to 4 $\mathrm{mg} / \mathrm{L}$, which is also less than the typically used dosages for the coagulation process. The maximum removal efficiency was attained in higher ranges of alum $(3.5-4 \mathrm{mg} / \mathrm{L})$, but in nitrate concentrations of more than $30 \mathrm{mg} / \mathrm{L}$, it had a negligible efficiency. Ayyasamy et al studied the removal of remained nitrate from groundwater samples using chemical coagulation after a one-stage biological treatment. They reported that the optimum dosage of alum for the removal of nitrate at a concentration of $50 \mathrm{mg} / \mathrm{L}$ was $150 \mathrm{mg} / \mathrm{L}$ and removal efficiency of the process was $74.3 \%$ (10). In this dosage of alum, the residual aluminum concentration in water treated by the coagulation process may be above the guidelines of the WHO and the admissible limit set by the Institute of Standard and Industrial Research of Iran, and
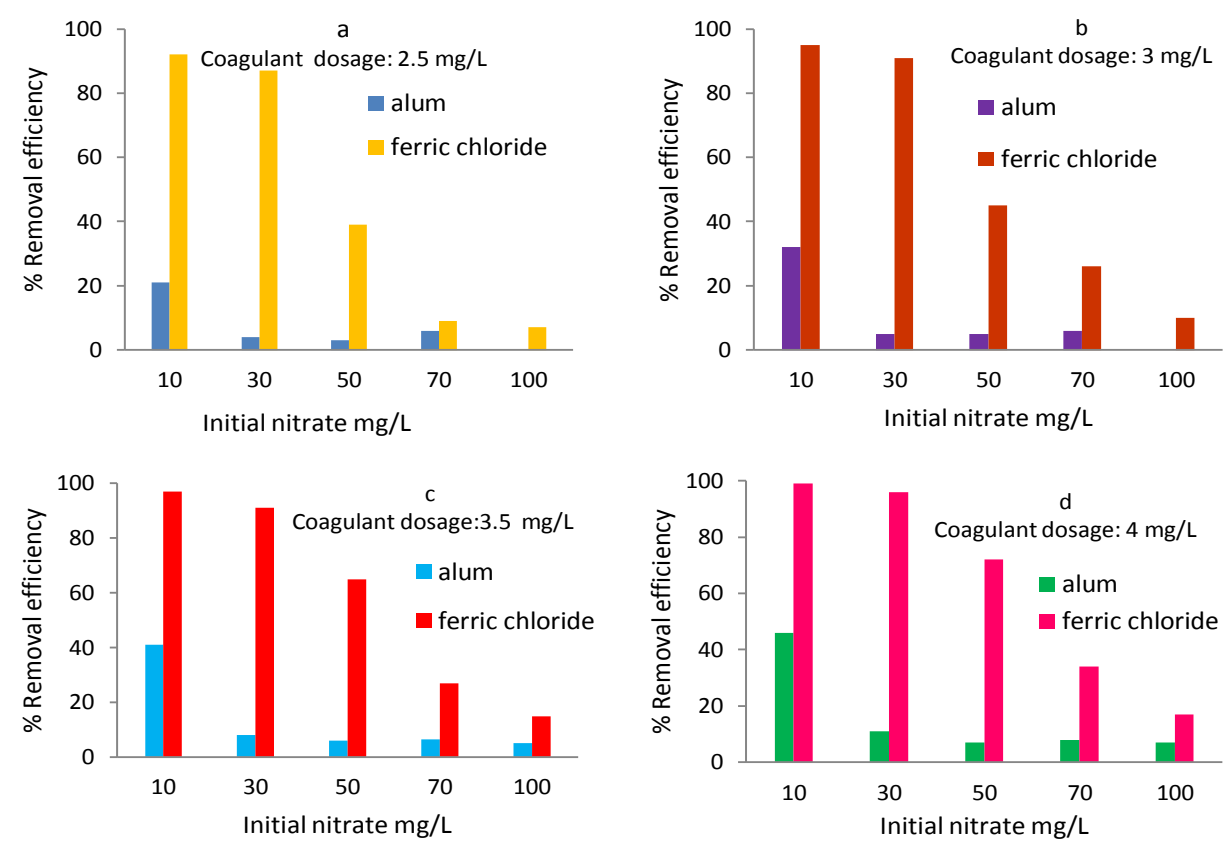

Figure 1. Efficiency of alum and ferric chloride in nitrate removal. 

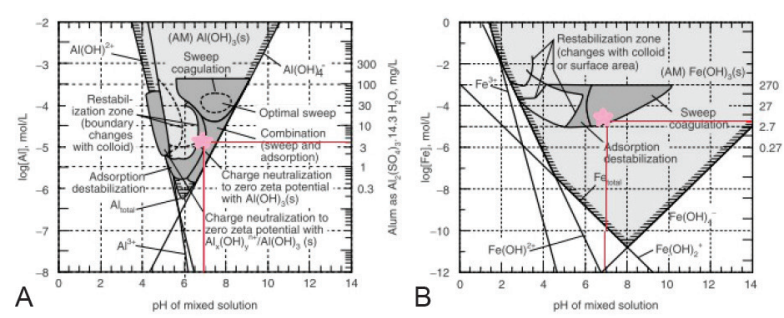

Figure 2. Typical operating ranges for coagulants: (A) alum and (B) ferric chloride (24).

it is suspected in Alzheimer disease (21).

Nitrate removal mechanism

To determine the nitrate removal mechanism using alum and ferric chloride coagulants, direct chemical reactions and adsorption mechanisms were appraised. As reported in the literature, for a chemical reaction between aluminum and nitrate or iron and nitrate, $\mathrm{pH}$ values should be raised above $9(24,25,28)$. However, due to the high stability and solubility of the chemical products of this reaction in water, nitrate removal was not expected in $\mathrm{pH}$ values above $9(24,25)$.

In $\mathrm{pH}$ values less than 9 , anions of $\mathrm{Cl}^{-}$and $\mathrm{SO}_{4}^{-}$could compete with nitrate for reduction by coagulants $\left(\mathrm{Cl}^{-}>\mathrm{SO}_{4}^{-2}>\right.$ $\mathrm{NO}_{3}^{-}$) (27). According to equations 1 and 2, adding alum and ferric chloride in the range of 3 to $4 \mathrm{mg} / \mathrm{L}$ could lead to the production of $\mathrm{HCl}$ and $\mathrm{H}_{2} \mathrm{SO}_{4}$; therefore, the range of the operating region diminished for iron and especially for aluminum hydroxide.

Eq. (1): $\mathrm{Al}_{2}\left(\mathrm{SO}_{4}\right)_{3} \cdot 14 \mathrm{H}_{2} \mathrm{O} \rightarrow 2 \mathrm{Al}(\mathrm{OH})_{3}+3 \mathrm{H}_{2} \mathrm{SO}_{4}+8 \mathrm{H}_{2} \mathrm{O}$

Eq. (2): $\mathrm{FeCl}_{3} \cdot 6 \mathrm{H}_{2} \mathrm{O} \rightarrow \mathrm{Fe}(\mathrm{OH})_{3}+3 \mathrm{HCl}+3 \mathrm{H}_{2} \mathrm{O}$

Since the initial $\mathrm{pH}$ was 7 , nitrate removal could not be achieved by a chemical reaction. Hence, bulk reactions for nitrate removal by ferric chloride and alum were adsorption and sweep precipitation (see Figure 2) (24).

Comparison of alum and ferric chloride abilities in removing nitrate

Based on the results, an initial ferric chloride dose of 4 $\mathrm{mg} / \mathrm{L}$ induced a reduction in nitrate concentration from $70 \mathrm{mg} / \mathrm{L}$ to less than the WHO guideline value $(50 \mathrm{mg} / \mathrm{L}$ as $\mathrm{NO}_{3}$ ) (13). Alum efficiency, however, was not sufficient. As previously stated, ferric ions are better than aluminum ions for adsorption and sweep coagulation because a lower dosage is needed.

Comparing the solubility of alum and ferric chloride showed that ferric chloride is more insoluble than aluminum in a wide range of $\mathrm{pH}$ values. Moreover, adding alum in ranges of 3.5 to $4 \mathrm{mg} / \mathrm{L}$ could lead to the production of $\mathrm{H}_{2} \mathrm{SO}_{4}$ and decreased $\mathrm{pH}$. Therefore, the optimum range of $\mathrm{pH}$ for alum is less than that for ferric chloride, and decreases in $\mathrm{pH}$ values are greater with alum than with ferric chloride. Therefore, the application of ferric chloride could be more effective than alum for the removal of nitrate in a water treatment plant.

The high stability and solubility of nitrate in water makes the removal of this anion from water sources with high nitrate concentrations difficult $(11,29)$. As such, various chemical and biological methods have been examined for their ability to remove this soluble anion. Some types of treatment methods should be considered highly experimental since there are currently no full-scale applications, such as biological treatment, subsurface biological treatment, phytoremediation, and nanotechnology (e.g., using nanoscale $\mathrm{ZVI}, \mathrm{SiO}_{2}-\mathrm{FeOOH}$, polyvinyl alcohol/polymer composites, etc.) (30-33).

Although conventional treatment methods such as ion exchange, reverse osmosis, electrodialysis, and biological denitrification are feasible, effective options for nitrate removal from potable water, their applications have some limitations.

\section{Conclusion}

The main objective of the current study was to evaluate the ability of conventional water treatment processes to reduce nitrate contamination. Although the studied method is not a specialized or ideal technology for the treatment of nitrate, it may be used in some circumstances to reduce the health risks associated with nitrate contamination of drinking water. As the results of this study showed, the conventional coagulation process using alum and ferric chloride could be effective in removing nitrate at concentrations less than $50 \mathrm{mg}-\mathrm{NO}_{3} / \mathrm{L}$; ferric chloride exhibited a greater removal efficiency than alum. Therefore, the use of ferric chloride for water treatment, even in common dose ranges, can play a basic role in the removal of nitrate from water.

\section{Acknowledgements}

The authors appreciate the support provided by Urmia University of Medical Sciences as project numbers 92-0134-1126 and 92-01-34-1187.

\section{Ethical issues}

The authors hereby certify that all data collected during the study is as stated in this manuscript, and no data from the study has been or will be published separately elsewhere.

\section{Competing interests}

The authors declare that they have no competing interests.

\section{Authors' contributions}

All authors contributed equally and were involved in the study design, data collection, and article approval.

\section{Reference}

1. Loganathan P, Vigneswaran S, Kandasamy J. Enhanced removal of nitrate from water using surface modification of adsorbents - a review. J Environ Management 2013; 131: 363-74.

2. Ota K, Amano Y, Aikawa M, Machida M. Removal of nitrate ions from water by activated carbons (ACs)-influence of surface chemistry of ACs and coexisting chloride and sulfate ions. Appli Surf Sci 2013; 276: 838-42. 
3. Bhatnagar A, Kumar E, Sillanpää M. Nitrate removal from water by nano-alumina: Characterization and sorption studies. Chem Eng J 2010; 163(3): 317-23.

4. Della Rocca C, Belgiorno V, Meriç S. Overview of in-situ applicable nitrate removal processes. Desalination 2007; 204(1-3): 46-62.

5. Khorsandi H, Mohammadi A, Karimzadeh S, Khorsandi J. Evaluation of corrosion and scaling potential in rural water distribution network of Urmia, Iran. Desalination and Water Treatment 2015; 57(23): 10585-92.

6. Nanbakhsh H, Mohammadi A, Ebrahimi A. Investigating of nitrate and nitrite concentration of drinking water wells in villages around of the industrial park. Health System Research 2010; 6: 881-88. [In Persian].

7. Barbooti MM, Bolzoni G, Mirza IA, Pelosi M, Barilli I, Kadhum R, et al. Evaluation of quality of drinking water from Baghdad, Iraq. Sci World J 2010; 5(2): 35-46.

8. Alabdula'aly AI, Al-Rehaili AM, Al-Zarah AI, Khan MA. Assessment of nitrate concentration in groundwater in Saudi Arabia. Environ Monit Assess 2010; 161(1-4): 1-9.

9. Rizk ZS. Inorganic chemicals in domestic water of the United Arab Emirates. Environ Geochem Health 2009; 31(1): 27-45

10. Ayyasamy PM, Shanthi K, Lakshmanaperumalsamy P, Lee SJ, Choi NC, Kim DJ. Two-stage removal of nitrate from groundwater using biological and chemical treatments. J Biosci Bioeng 2007; 104(2): 129-34.

11. Song H, Zhou Y, Li A, Mueller S. Selective removal of nitrate from water by a macroporous strong basic anion exchange resin. Desalination 2012; 296: 53-60.

12. McAdam E, Judd S. A review of membrane bioreactor potential for nitrate removal from drinking water. Desalination 2006; 196(1-3): 135-48.

13. World Health Organization. Guidelines for DrinkingWater Quality. Geneva: WHO; 2008.

14. Drinking Water Contaminants - Standards and Regulations. http://www.epa.gov/dwstandardsregulations. 2016.

15. Yousefi Z, Motallebi R, Takdastan A. Water desalination by membrane technology (RO) in southern Iran (Jask city). Environmental Health Engineering and Management 2014; 1(1): 13-8.

16. Sharma SK, Sobti RC. Nitrate removal from ground water: a review. J Chem 2012; 9(4): 1667-75.

17. Jensen VB, Darby JL, Seidel C, Gorman C. Drinking water treatment for nitrate Davis. Center for Watershed Sciences, University of California; 2012.

18. Mosaferi M, Nemati S, Khataee A, Nasseri S, Hashemi AA. Removal of Arsenic (III, V) from aqueous solution by nanoscale zero-valent iron stabilized with starch and carboxymethyl cellulose. J Environ Health Sci Eng 2014;
12: 74 .

19. Baruth EE. Water Treatment Plant Design (American Water Works Association, and American Society of Civil Engineers). 4th ed. New York: McGraw-Hill; 2005.

20. Zhou T. Removal of organic micropollutants by coagulation in wastewater treatment. Delft University of Technol; 2011.

21. Aghapour AA, Mohammadi A. Investigating the coagulation efficiency of PACI in removal of water turibidty in Shahrchay river in Orumia and its health effects. Health System Research. 2011; 6(4): 762-9. [In Persian].

22. Jiang JQ, Lloyd B. Progress in the development and use of ferrate (VI) salt as an oxidant and coagulant for water and wastewater treatment. Water Res 2002; 36(6): 1397-408.

23. Pernitsky DJ, Edzwald JK. Selection of alum and polyaluminum coagulants: princip applic. Journal of Water Supply: Research and Technology - AQUA 2006; 55(2): 121-141.

24. Crittenden JC, Trussell RR, Hand DW, Howe KJ, Tchobanoglous G. MWH's Water Treatment: Principles and Design. Wiley; 2012.

25. Murphy AP. Chemical removal of nitrate from water. Nature 1991; 350: 223-5

26. Koparal AS, Öğütveren ÜB. Removal of nitrate from water by electroreduction and electrocoagulation. J Hazard Mater 2002; 89(1): 83-94.

27. Bhatnagar A, Sillanpää M. A review of emerging adsorbents for nitrate removal from water. Chem Eng J 2011; 168(2): 493-504.

28. Lacasa E, Cañizares P, Sáez C, Fernández FJ, Rodrigo MA. Removal of nitrates from groundwater by electrocoagulation. Chem Eng J 2011; 171(3): 1012-7.

29. Murkani M, Nasrollahi M, Ravanbakhsh M, Bahrami P, Jaafarzadeh Haghighi Fard N. Evaluation of natural zeolite clinoptilolite efficiency for the removal of ammonium and nitrate from aquatic solutions. Environmental Health Engineering and Management 2015; 2(1): 17-22.

30. Selecky M, Adair J, Clifford D. Nitrate Treatment Alternatives for Small Water Systems. http://www.doh. wa.gov/ehp/dw. Published 2005.

31. Khalil AM, Eljamal O, Jribi S, Matsunaga N. Promoting nitrate reduction kinetics by nanoscale zero valent iron in water via copper salt addition. Chem Eng J 2016; 287: $367-$ 80 .

32. Ensie B, Samad S. Removal of nitrate from drinking water using nano $\mathrm{SiO} 2-\mathrm{FeOOH}-\mathrm{Fe}$ core-shell. Desalination 2014; 347: 1-9.

33. Rajeswari A, Amalraj A, Pius A. Adsorption studies for the removal of nitrate using chitosan/PEG and chitosan/PVA polymer composites. Journal of Water Process Engineering 2016; 9: 123-34 